${ }^{14}$ HUDSON, J.H. 1976. 1974 plant records from Saskatchewan, rediscoveries, discoveries and other curiosities. Blue Jay 34(1):9-13.

${ }^{15}$ HUDSON, J.H. 1977. Rare and endangered native plants in Saskatchewan south of Lat. $55^{\circ}$. Blue Jay $35(3): 126-137$

${ }^{16} \mathrm{HUDSON}$, J.H. A second Evening Star in Saskatchewan - Blue Jay 42(1):2021.

${ }^{17}$ MAHER, R.V., G.W. ARGUS, V.L. HARMS, and J.H. HUDSON. 1979. The Rare
Vascular Plants of Saskatchewan. Syllogeus No. 20, National Museum of Natural Sciences. Ottawa, Ontario. 55 pp. + maps (p. 33).

18SCOGGAN, H.J. 1978. Flora of Canada, Park 2. Pteridophyta, Gymnospermae, Monocotyledoneae. National Museums of Canada, Ottawa. 1711 pp. (p. 542).

${ }^{19}$ WHITE, D.J., and K.L. JOHNSON. 1980. The Rare Vascular Plants of Manitoba. Syllogeus No. 27. National Museum of Natural Sciences, Ottawa, Ontario. 52 pp. + maps (p. 29).

\title{
A SECOND EVENING STAR IN SASKATCHEWAN
}

JOHN H. HUDSON, 103 Richmond Crescent, Saskatoon, Saskatchewan. S7N 1 A9

In June 1982 I had the opportunity to go along on a field trip to Val Marie set up as a post-convention tour by the Canadian Botanical Association. One of the stops was 70-Mile Butte, on the north side of the Frenchman, some five miles down-river from Val Marie (but of course longer by trail). The group was wandering over a steep south-facing slope of bentonitic clay when George Ledingham and Gordon Thomas from the Regina Research Station came up to me with a plant for identification. While I was puzzling over it, for I had never seen it before, I was told by George that Mr. Thomas had offered to bet him $\$ 25.00$ that I didn't know it, and George had a good mind to take him up on this bet. I said, "You would have lost, for I don't know it - never saw it before. However, l'd tentatively guess Loasaceae, because of the extreme roughness of the leaves".

You may be sure I, too, collected some material and when I got home it proved to be a Mentzelia albicaulis Dougl., known in Canada hitherto only in the dry interior of British Columbia. Collection data are as follows: "Hudson 4208, Val Marie, SeventyMile Butte, LSD 15 in 11-3-XIII W. 3rd. Dry south-facing annual-inhabited coulee slope, soil loose chunky bentonitic clay, lying at angle of repose".

The general appearance of the plant is not a bit like its larger relative 
Evening Star ( $M$. decapetala); instead of 10 white petals 5 or $10 \mathrm{~cm}$ long, its flowers have 5 yellow petals something like $5 \mathrm{~mm}$ long. It is an annual about the size and strict build of Tarweed (Madia glomerata) or the smaller Willow-herbs. The oblong to linear leaves are serrate to pinnatifid below, subentire above. The flowers must be night-blooming, for they were not open in the light of morning when first we saw it. The pods are reasonably obvious, some $2 \mathrm{~cm}$ long and 3-4 mm diameter, green, ribbed and plainly tipped by the remains of the flower. About the only good field mark would be the extreme roughness of the leaves from hooked hairs - they feel like so much emery paper. The plant seems to have no English name given in floras; one might translate the Latin name as White-stemmed Evening Star. The

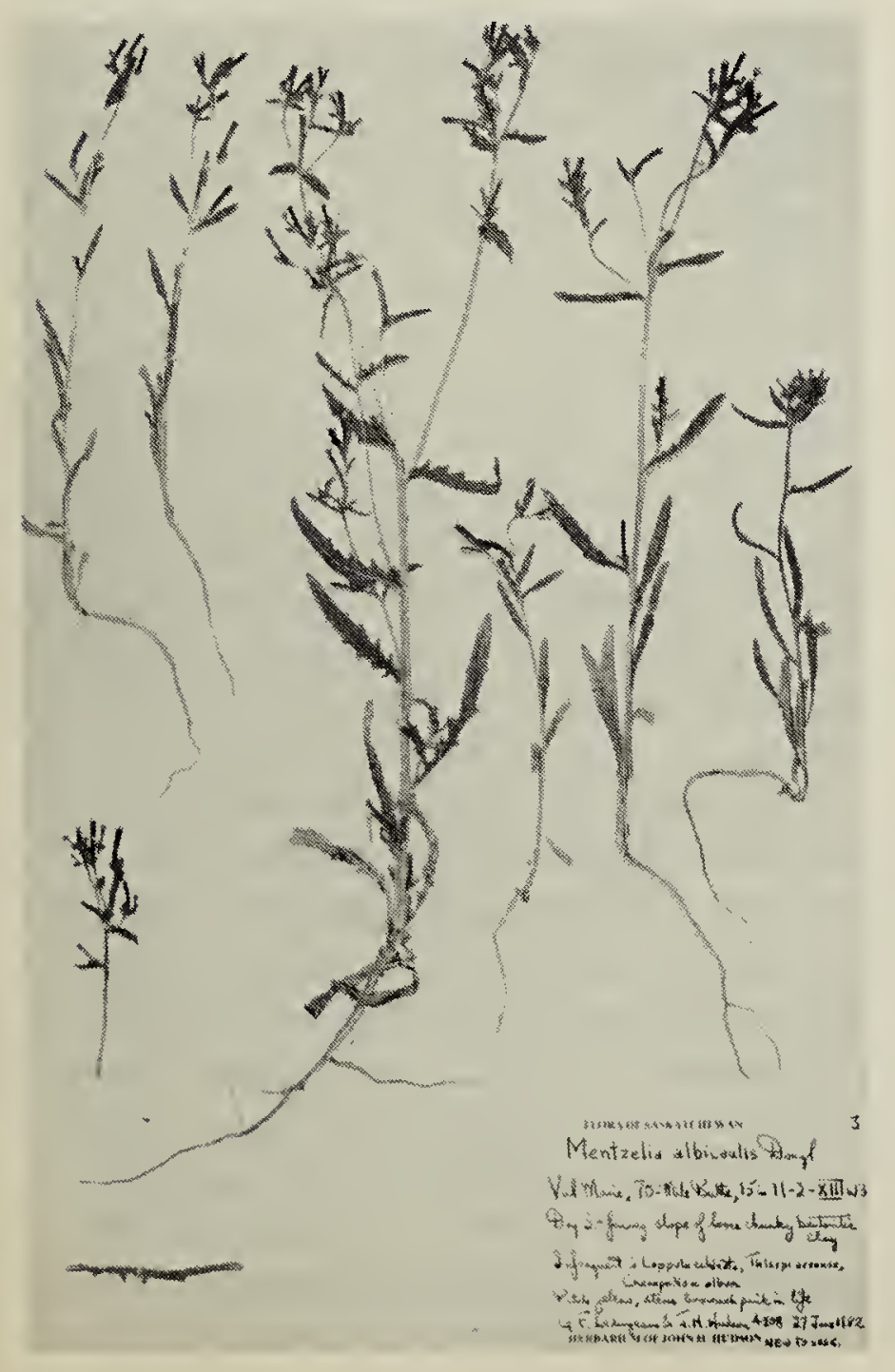

stems are reported to grow conspicuously white in age, although they were flesh pink in this material.

Apart from this record, 1982 and 1983 did not give me much in the line of surprises. In both summers we spent a fortnight with a daughter and son-inlaw at their lodge near Southend on Reindeer Lake. I collected a fair number of plants I hadn't seen before, but to list them in full here would be a rehash of the Heilman-Ternier collections listed in Rhodora 82 (830), 239280, (1980). Perhaps worth mentioning are \#4258, Bog Adder's-mouth (Malaxis paludosa (L) Sw) from a floating bog at the mouth of the Little Deer R., $56^{\circ} 201 / 2^{\prime \prime} \mathrm{N}, 103^{\circ} 18^{\prime} \mathrm{W}$; and \#4291, Alaskan Club-moss (Lycopodium sabinaefolium Willd. var sitchense (Rupr.) Fern.) from a stunted pine wood on lichen-covered sandy soil, $56^{\circ} 16^{\prime} \mathrm{N}, 103^{\circ} 33^{\prime} \mathrm{W}$. I should add a sight record at a second locality for Bog Adder's-mouth at a bog some 12 mi. W. of \#4258, at $56^{\circ} 22^{\prime} \mathrm{N}, 103^{\circ} 34 \frac{1}{2} 2^{\prime}$ W.

In more southern parts of Saskatchewan, the only collection of mine worth noting, and that only as a range extension, was \#4311, Meadow Sedge (Carex granularis Muhl.), from the upper calcareous margin of a groundwater seep, on the river, northeast of Rosthern, at a location which could be called S. edge S.E. $1 / 4$ 7-43-I W.3rd if the land were not laid out in the old river lots.

EDITOR'S NOTE: In Britton and Brown, An Illustrated Flora of the Northern United States and Canada, the common name given is White-stemmed Mentzelia. 